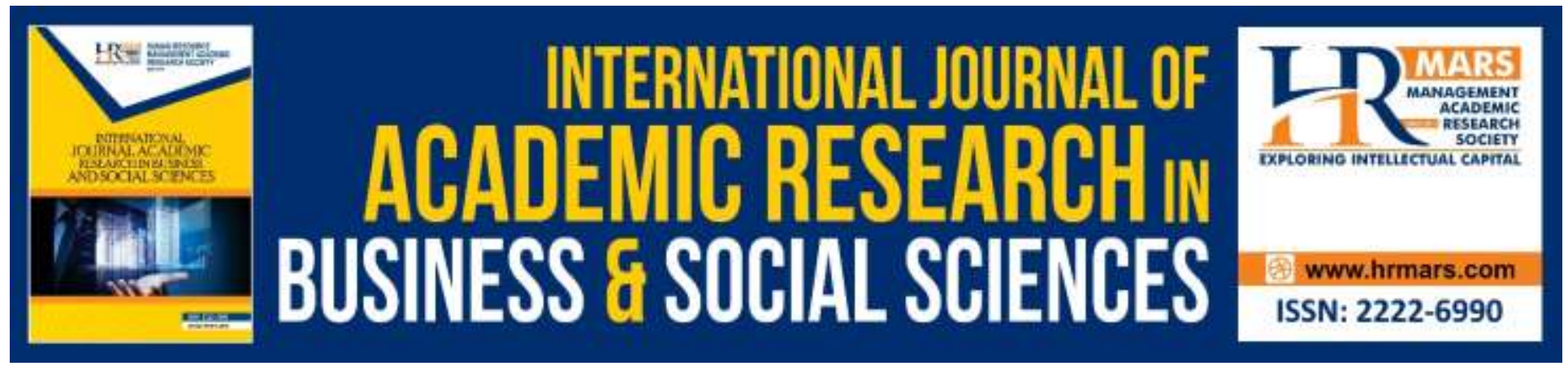

\title{
Minimizing Unemployment of Graduates through Technical Education and Training: Meta-Analysis Approach in Nigeria
}

\author{
Shirka Kassam Jwasshaka, Nor Fadila
}

To Link this Article: http://dx.doi.org/10.6007/IJARBSS/v10-i2/6858

DOI:10.6007/IJARBSS/v10-i2/6858

Received: 02 January 2020, Revised: 21 January 2020, Accepted: 30 January 2020

Published Online: 09 February 2020

In-Text Citation: (Jwasshaka \& Fadila, 2020)

To Cite this Article: Jwasshaka, S. K., \& Fadila, N. (2020). Minimizing Unemployment of Graduates through Technical Education and Training: Meta-Analysis Approach in Nigeria. International Journal of Academic Research in Business and Social Sciences, 10(2), 34-44.

\section{Copyright: (C) 2020 The Author(s)}

Published by Human Resource Management Academic Research Society (www.hrmars.com)

This article is published under the Creative Commons Attribution (CC BY 4.0) license. Anyone may reproduce, distribute, translate and create derivative works of this article (for both commercial and non-commercial purposes), subject to full attribution to the original publication and authors. The full terms of this license may be seen at: http://creativecommons.org/licences/by/4.0/legalcode

Vol. 10, No. 2, 2020, Pg. $34-44$

Full Terms \& Conditions of access and use can be found at http://hrmars.com/index.php/pages/detail/publication-ethics 


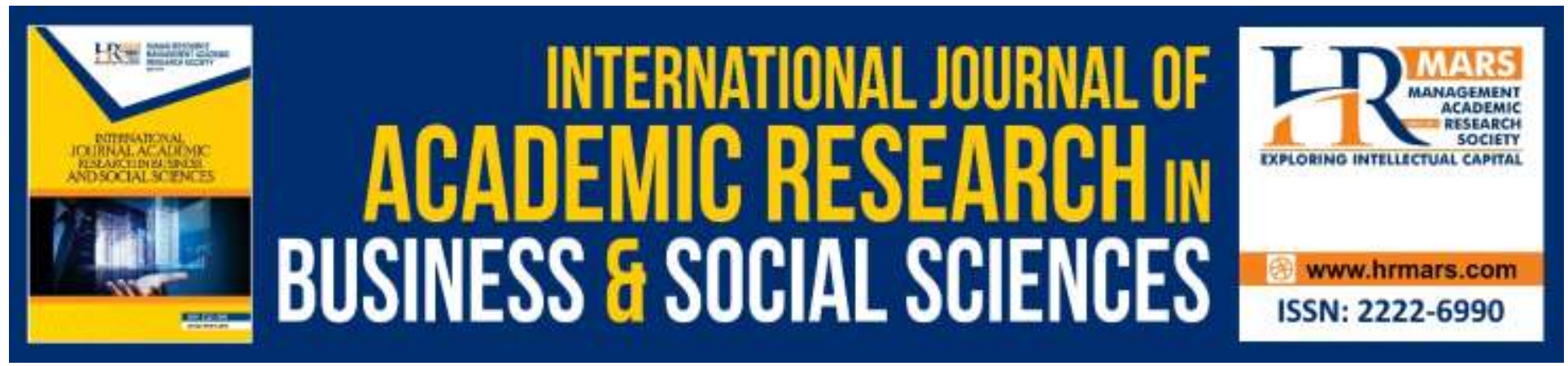

\title{
Minimizing Unemployment of Graduates through Technical Education and Training: Meta-Analysis Approach in Nigeria
}

\author{
Shirka Kassam Jwasshaka \\ Plateau State Polytechnic, Barkin Ladi - Nigeria, School of Technical Education \\ Email: cassak4real@yahoo.ca \\ Nor Fadila \\ University of Technology, Skudai Johor Bahru, Malaysia \\ Faculty of Social Sciences and Humanities
}

\begin{abstract}
This study was a meta-analysis approach involving 35 published journal articles related to minimizing unemployment among Nigeria graduates through Technical Vocational Education and Training (TVET). The related materials were downloaded from web data base using keywords such as; Technical education in Nigeria as a panacea for unemployment of youths, role of TVET in skill training were some of the keywords used to select the relevant materials from data webbased providers like; Science direct, Google scholar, Springer and Willey online library. 35 published Journals articles were downloaded and reviewed for the study but only 16 journals out of the 35 were found to have met the requirements of the study. The finding of the meta-analysis revealed that most of the study carried out laid emphasis on TVET as a tool for poverty reduction among youths. Only few of the literatures discussed on matters that relates to Nigeria graduates' unemployment and strategies for its reduction. Some recommendations were stated which included a holistic revamping of TVET among others. Suggestions for further studies were outlined.
\end{abstract}

Keywords: Graduates, Technical, Vocational Education and Training, Unemployment. 


\section{Introduction}

Unemployment in this context could be defined as the inability of a graduate to earn a living through paid job from neither the government nor the private sector after graduation from school. Nigeria is one of the developing nations of the world that is faced with the issues of graduate unemployment which may be attributed to graduates lack of up-to-date workforce skills. Torruam and Abur 2014; Njoku and Ihugba 2011) observed that one of the greatest challenges facing Nigeria over the years is the rising trend in unemployment. The scorching consequences of this is the eminent high level poverty, inequality, and rising rate of criminality (Afolabi, Kareem, Okubanjo, Ogunbanjo, \& Aninkan, 2019). Corroborating this assertion Sulayman \& Philo (2015); Ayanyemi, \& Adelabu, (2016) added that unemployment is liable of causing poverty and other social vices in the society. A functional and effective technical education and training programe is capable of providing graduates with skills that can make them employable and be self-reliant.

Developed nations like Canada, Australia, Germany, Singapore, and Japan have ripped the benefit of Technical, Education and Training to become global leaders in all aspect of their enterprise in a very short space of time. But Nigeria is bedeviled with mass graduates' unemployment because of lip services paid to skill acquisition programs.

Records available from Bureau of Statistics (2018); Salleh, Jusoh, Embong \& Mamat (2018); Tzotzou, (2016); Kai, Rahman (2018), showed that from the past few years, the unemployment rate is on the increase in Nigeria. The record indicated a steady increase between 2015 and 2018 from $6.4 \%$ to $23.1 \%$ respectively as at third quarter of the year 2018 . It may increase beyond this if proactive measures are not taken by the relevant authorities to minimize the monster. This would also be a serious threat towards achieving goal 4 item 4.4 of Sustainable Development Goals by 2030 where emphasis is laid on substantially increasing the number of youth and adults who have relevant skills, including technical and vocational skills, for employment, decent jobs and entrepreneurship (Future \& Education, n.d.)

4.5. A functional Technical, Education and Training (TVET) can salvaged this ugly situation. According to Federal Republic of Nigeria (FRN) (2013), objectives of TVET among others are to:

i. Provide trained manpower in applied science, technology and commerce particularly at subprofessional levels.

ii. Give training and impart the necessary skills leading to the production of craftsmen, technicians and other skilled personnel who will be enterprising and self-reliant

iii. Provide people who can apply scientific knowledge to the improvement and solution of environmental problems for the use and convenience of man.

In order to nib the menace of unemployment in the bud government have a responsibility to have and effective TVET-Industry collaboration in meeting the stated objectives.

Every year, a thousand graduates are being turned into the labor market with few job opportunities to accommodate them or rather with insufficient employability skills. Most of the literatures indicated that unemployment among the youth contributes to political unrest across the nation. The finding from the meta-analysis attested to the fact that Technical, Education and Training can play a critical part in minimizing this menace, through equipping graduates with the skills that can make them be self-reliant. It is almost inconceivable to say unemployment can completely be eradicated, but frantic efforts can be constituted to take it down to the barest minimum. It is on this 
premise that the researcher believed Technical Education and training should be stressed. Besides the acquisition of technical skills, Federal Republic of Nigeria, (2013 emphasized that distributive education which is an aspect of vocational education is capable of providing employable skills to graduate also. The author observed that most Nigerian youths are unemployed because they lack skills that could get them to stand on their own. Distributive education could equip them with selfreliance skills too. It is always devastating to parents to see graduates roaming the street after spending so much on them in order to make them useful to the society.

United Nations Education, Scientific and Cultural Organization (UNESCO, 2009) defined Technical Vocational Education and Training (TVET) as learning, aims at developing skills in the practice of certain trades, as well as learning; aims at educating pupils for entrance into the labor market in general as cited in Federal Republic of Nigeria, (2013. This aspect of education is widely recognized as the key to any nation becoming technologically relevant and internationally competitive in the world market. TVET can pave way for abundance of opportunities for human resource capital and rich economies. The author added that TVET also plays important function in the socioeconomic growth of a country. Sulayman \& Philo (2015); Ayanyemi, \& Adelabu, (2016) observed that there is a close bond between unemployment and poverty with direct bearings on the economy and graduates. It is sufficing to say therefore that when there is a high unemployment rate in a nation, the economic system can be affected and poverty can set in. Chukwuma, $(2015$,$) Observed that a$ well-structured TVET system can enhance individuals' productivity, employment, promote social relevance, and entrepreneurial competiveness.

In spite of the importance of TVET in minimizing unemployment, Emmanuel (2014), and Marcel-Okafor, (2017) unanimously observed that its development has been bedeviled by serious challenges in the last few decades. The attendant consequences are that rather than creating jobs for themselves a great number of graduates' work in search for blue collar jobs because of deficiency of skills Shirama, \& Dahiru (2014).

It is observed that graduates who cannot survive this hardship of lack of employment are prone to criminal tendencies, moreover, the politicians can take advantage of their situation and utilize them as thugs during election. Scholars has attributed youth unemployment as being responsible to different dimensions of social vices experienced in Nigeria (Wayas, Selvadurai, \& Awang, 2019). Corruption is dominant in most of the vital sector of the economy perhaps this is also responsible for the unpleasant development. Government has made various efforts to addressing this ugly trend, but the efforts does not yield any positive result because of political interest and lack of continuity of government programs.

Most of the article reviewed focused their studies on poverty and youth unemployment as a whole, neglecting the educated but without employable skills 'the graduates'. This study, therefore intends to focus on graduates who have the certificates yet not gainfully employed or self-reliant. The review recognized that areas like entrepreneurship skills, Technical skills and Agricultural Skills which are critical in providing employability skills to graduates were omitted by the writers.

\section{Research Questions}

The study was a meta-analysis of journal articles that relates to Technical and Vocational Education, as a system of education that can minimize the rate of unemployment in Nigeria among 
INTERNATIONAL JOURNAL OF ACADEMIC RESEARCH IN BUSINESS AND SOCIAL SCIENCES

Vol. 10, No. 2, Feb, 2020, E-ISSN: 2222-6990 (C) 2020 HRMARS

graduates. The research targeted at identifying dominant views of researchers on how unemployment can be minimized in Nigeria with special interest on graduates. The following research questions were formulated which, gave a lead way to minimizing the scorch of unemployment among Nigeria graduates.

- What are the causes and consequences of unemployment among Nigerian Graduates?

- How can unemployment be minimized among Nigerian graduates through TVET?

\section{Methodology}

\section{Strategies for Data Collection and Analysis}

Various published journal articles were searched online from an online database of the Educational Resources Information Centre (ERIC) through different network-based service provider. The database includes; Google scholar, Science direct, Wiley online library and Springer link. The researchers were so selective to ensure that only relevant journal article related to TVET were scanned and printed.

Additional information was sought through papers presented at conferences also. Some of the key words used that led to the related education materials were; Technical training in Nigeria, the role of TVET in Skill acquisition, Entrepreneurship through TVET, the role of TVET in the employment of young people.

The published journal papers reviewed were those within the ranges of 2011 to 2018. A total of 35 published journal articles that talks about TVET with regards to unemployment were downloaded and reviewed, but only 16 were used because they satisfied the demand of the researchers. Some of the published journal articles were rejected because they talked about Youths unemployment as a whole, some poverty and some do not have clear methodology and findings. The relevant articles were assigned numbers in the order of authors as shown in meta- analysis table below for easy analyses. 
INTERNATIONAL JOURNAL OF ACADEMIC RESEARCH IN BUSINESS AND SOCIAL SCIENCES

Vol. 10, No. 2, Feb, 2020, E-ISSN: 2222-6990 @ 2020 HRMARS

Table. 1.1. Summary of meta-analysis showing approaches and findings

\begin{tabular}{|c|c|c|c|}
\hline AUTHORS & APPROACHES & CATEGORY & FINDINGS \\
\hline $\begin{array}{l}\text { Okwelle \& Deebom, } \\
\text { (2017) [1] }\end{array}$ & $\begin{array}{l}\text { Descriptive } \\
\text { survey }\end{array}$ & Youths & TVET Skill acquisition \\
\hline Afolabi et al. (2019) [2] & Desk review & Youths & $\begin{array}{l}\text { Enhancing Entrepreneurship } \\
\text { education policy }\end{array}$ \\
\hline $\begin{array}{l}\text { Ayanyemi \& Adelabu (2016) } \\
\text { [3] }\end{array}$ & Desk review & Youths & $\begin{array}{l}\text { Shortage of teaching and learning } \\
\text { facilities, unconducive teaching } \\
\text { environment, irrelevant training } \\
\text { programs, societal attitudes }\end{array}$ \\
\hline Chukwuma (2015) [4] & Desk review & Graduates & TVET Skills \\
\hline Nwojie (2014) & $\begin{array}{l}\text { Theoretical } \\
\text { framework }\end{array}$ & Rural dwellers & $\begin{array}{l}\text { TVET can reduce poverty among } \\
\text { rural inhabitants }\end{array}$ \\
\hline $\begin{array}{l}\text { Ugochukwu, \& Marel (2017) } \\
\text { [6] }\end{array}$ & Descriptive survey & $\begin{array}{l}\text { Graduate } \\
\text { performance in } \\
\text { Architecture }\end{array}$ & $\begin{array}{l}\text { Core courses prepare graduates } \\
\text { for the limited challenges in } \\
\text { design and blueprinting }\end{array}$ \\
\hline $\begin{array}{l}\text { Sarimah \& Dahiru (2014) } \\
\text { [13] }\end{array}$ & $\begin{array}{l}\text { Analytical review } \\
\text { procedures }\end{array}$ & $\begin{array}{l}\text { Review of } \\
\text { University of } \\
\text { Tech. Curriculum }\end{array}$ & $\begin{array}{l}\text { Core skills are missing in the } \\
\text { curriculum }\end{array}$ \\
\hline $\begin{array}{l}\text { Ogbonaya \& Ekereobong } \\
(2015)[8]\end{array}$ & Desk review & Youths & $\begin{array}{l}\text { Advocate for adequate funding, } \\
\text { Planning, Implementation of } \\
\text { TVET, provision of adequate } \\
\text { facilities and consumables }\end{array}$ \\
\hline $\begin{array}{l}\text { Patrick \& Brodmann (2016) } \\
\text { [9] }\end{array}$ & & $\begin{array}{l}\text { University } \\
\text { Graduates }\end{array}$ & $\begin{array}{l}\text { Advocate for entrepreneurship } \\
\text { for self-employment }\end{array}$ \\
\hline Oluyomibo (2016). [10] & Desk review & Graduates & \\
\hline Peter (2014) [11] & Desk review & Youths & \\
\hline Uddin (2013) [12] & & Youths & $\begin{array}{l}\text { Reveals that TVET played } \\
\text { significant role in reducing } \\
\text { poverty among Graduates. }\end{array}$ \\
\hline Afolayan (2016) [15] & Survey & $\begin{array}{l}\text { Undergraduate/ } \\
\text { graduates }\end{array}$ & $\begin{array}{l}\text { Effective integration of } \\
\text { employability in Educational } \\
\text { system }\end{array}$ \\
\hline Emmanuel (2014) [16] & Desk Review & Youths & $\begin{array}{l}\text { Suggested increase funding and } \\
\text { access to TVET programs }\end{array}$ \\
\hline
\end{tabular}

Table. 1.1 above showed some of the Journals reviewed for the purpose of this study. The table showed the approaches, the scope of various fields and the findings obtained.

\section{Results and Discussion}

\section{Causes and Effects of graduates' unemployment}

From Table1 above, it could be observed that most studies carried out focused only on Youths in general regardless of whether educated or not. The implication is that graduates who have gone through the four walls of the classroom are marginalized because these is a group that have a higher 
expectation of getting employed than those that are not educated. Ayanyemi, \& Adelabu (2016); Nwojie, \& Chidinma (2014); Peter (2014) and Uddin (2013) acknowledged in their studies the fact that unemployment has negative consequences on the economy and the security stability of any society. Perhaps this is the reason for high magnitude of poverty and in stability of peaceful coexistence of most societies in Nigeria today.

The survey discovered that proper funding, planning and organization of TVET Institutions can help minimized graduates' unemployment Sulayman \& Philo, (2015); Ogbanaya, \& Ekereobong, (2015); Jane, Raymond, Patrick, and Uddin, (2017). Core skills are likewise noted to be lacking in the curriculum of universities Shirama, \& Dahiru, (2014); Audu, Yusri, Aede Hatib, Muhammed, \& Mohd. Zolkifli (2014). The findings in Okwelle, \& Deebom, (2017) revealed that equipping graduates with relevant TVET skills will prepare them to build small and medium scale commercial enterprise. By so doing will reduce over dependence of graduates on government paid jobs that are not easy to find. The proper teaching of courses like drafting and architectural design cannot be overemphasized for those in the technical course Shirama, \& Dahiru, (2014). There is no doubt, therefore that having competent skills in design of buildings will provide food on the table of a graduate thereby reducing poverty.

Poverty is an unhealthy phenomenon of the society and the country at large; it results in a number of issues like frustration, loss of hope, and loss of prospect or value Ayanyemi, \& Adelabu (2016). In spite of efforts by the successive Nigeria government through the initiation of various intervention programs in minimizing graduates' unemployment, the trend still persists because the programs were flawed by lack of supervision, misplace of priority areas and lack of political good will among others Okwelle, \& Deebom, (2017); Sulayman \& Philo, (2015); Ayanyemi, \& Adelabu (2016); Chukwuma, (2015); Ugochukwu, \& Marel, (2017).

The society also does not place any value or dignity on graduates anymore because they lack relevant skills even though educated so they look at graduates as nuisance to the society. This finding is supported by study carried out by Ayanyemi, \& Adelabu (2016); Afloyan (2016) that employers of labor have continued to express worry over the quality of graduates of higher institutions who are experiencing set-backs as a result of lack of employability skills. Obtaining a higher certificate is good, but emphasis should be on psychomotor skills rather than cognitive and affective domain only. However, Shirama \& Dahiru, (2014); Afloya (2016, Sept) noted that acquisition of life skills can also augment the employability skills of graduates to make them more successful and happy individuals. Re-engineering Technical and vocational training centers, TVET programs, training and re-training of TVET personnel will travel a long way in halting the rate of unemployment in Nigeria because highly skilled and valued adding graduates can be produced Okwelle \& Deebom, (2017; Sulayman \& Philo, (2015); Ayanyemi, \& Adelabu, (2016); Ugochukwu, \& Marel, (2017).

\section{Minimize the Rate of Unemployment among Nigerian Graduates}

Most of the published Journals reviewed in table 1 above failed to talk about the internship program for graduates. Internship of graduates is really key in gaining employability skills. The researchers advocate for this to be included in the curriculum of TVET Institutions in Nigeria. In this program, graduates can be exposed to real life work situation with the private sector for a period of 
at least one and half year or more. Vocational training centers equip with relevant facilities can also assist providing internship services to graduates.

Various government interventions with regard to empowerment should be tailored towards skills not monetary gains alone. Adequate budgetary allocation for research and purchase of relevant training TVET facilities with a steady power supply to run heavy duty machines cannot be overemphasized in graduates' skill training.

TVET personnel should be challenged by the dynamism of the technological world to be able to attain training and retraining programs. If proper problem base learning (PBL) is adopted and managed it will expose the graduates to skills such as critical thinking and problem solving that will enhance their efficiency in the world of work. According to Nwojie. \& Chidinma (2014) effective collaboration of TVET institution with the industry in devising a means to financing, building, managing, preserving and equipping the graduates with the required work skills, unemployment will be a history in Nigeria.

\section{Further Suggestions}

It is a non-disputable fact that unemployment among Nigeria graduates is on the increase with attendant consequences of affecting the economy negatively. All stakeholders which include the academia, policy makers and private sectors are advocating for a way to minimize it. To minimize this menace, our education system needs a holistic revamping. Local craft which hitherto was taken as one of the mandatory subjects in the primary schools is no longer given priority. This is the foundation where students learn skills which gradually metamorphosed into their life choosing careers.

Employers of labor and the general public should always emphasize on what you can do as a person rather than placing priority on paper qualification as requirement for entry into any job; by so doing graduates can consider practical as one of the important components of their subjects. During long vacation, they can attach themselves to the private organizations to learn skills instead of staying idle. According to Afloya (2016); Patrick, \& Brodmann (2016) radical reform of Nigerian educational system to reflect the current reality of life can change the trend of events.

Nigeria alien companies like the Textile Industries, Ajakuta Steel Rolling Mills, Peugeot Assembly, Brick and Block Production Companies and so many others should be revamped so as to provide opportunities for graduates' internship training.

\section{Conclusion}

In conclusion, this study ex-rayed into causes and effects of unemployment among Nigeria, graduates and how to minimize it. It adopted meta-analysis approach to analyzed related published journal articles searched from different data-base provider. Base on the finding, most of the study conducted concentrated on Poverty reduction and Youths unemployment neglecting a particular section of the Youths who have gone through the four walls of the classroom and has obtained certificates but are unemployed. The researchers considered this group very important because the society in general and parent in particular have high expectation on them, having spent so much on their education.

The researchers are of the view that prioritizing TVET institutions of learning can bring positive result in minimizing unemployment problem in Nigeria. They also advocated for inclusion of TVET 
skill training modules in the curriculum of all levels of education in Nigeria so as to properly prepare graduates for labour market. The study will serve as a road map to the relevant stakeholders to see the need to prioritized technical education towards equipping the graduates with entrepreneurship and vocational competencies for self-reliant. Deeper study can be carried out on the political attachment to this lingering problem of unemployment among graduates in Nigeria.

\section{Acknowledgement}

We want to express our gratitude first to the esteem authors whose published articles are made accessible for us to achieve our desire in completing this work. We will not also forget to thank the management of University of Technology, Malaysia for creating an enabling environment for learning which made it possible for us to contribute our quota in this small measure to the body of knowledge and to proffer solution to societal problem.

\section{References}

Afloya, N. T. (2016). Graduate Employability: Key Challenges and Possible solutions: Paper presented at the Society of Petroleum Engineers, Technical Conference and Exhibition held in Dubai,UAE[Online],Available: https://www.spe.org/events/choc/2016/documents/16CHOC_Program.pdf

Afolabi, M. O., Kareem, F. A., Okubanjo, I. O., Ogunbanjo, O. A., \& Aninkan, O. O. (2019). Effect of Entrepreneurship Education on Self-Employment Initiatives among Nigerian Science \& Technology Students. Journal of Education and Practice, Vol. 8, pp. 44-51. Retrieved from https://search.proquest.com/docview/1913348830?accountid=12753

Ayanyemi, A. K., \& Adelabu, O. A. (2016). Revitalization of Technical and Vocational Education for Youth Empowerment and Poverty Alleviation in Nigeria. International Journal of Education Science, [Online] (13), 262-270.Available: https://www.tandfonline.com/doi/abs/ 10.1080/09751122.2016.11890460

Audu, R., Yusri, B. K., Hatib, A. B. M., Muhammed, S. B. S. \& Mohd. Zolkifli, A. H. (2014). Perception of Teachers and Administrators on the Teaching Methods that influence the Acquisition of Generic Skills. International Education Studies, [Online]7(11)40-45.Available: https://files.eric.ed.gov/fulltext/EJ107102_8.pdf

Chukwuma, E. M. (2015). Vocational and Technical Education: A Solution to Unemployment among Graduates. Journal of Policy and Development Studies, [Online] 9 (2), 90-94. Available: https://www.arabianjbmr.com/pdfs/JPDS_VOL_9_2/8.pdf

Emmanuel, E., I. (2014). Challenges Facing Technical and Vocational Education in Nigeria; Journal of Educational Policy and entrepreneurial Research [Online](JEPER) 1(1) 40-45.Available: http://www.iiste.org/Journals/index.php/JEPER/article/view/15382

Future, T. H. E., \& Education, O. F. (n.d.). Vision 2030.

Federal Republic of Nigeria. (2013). National Policy on Education. Lagos: NERDC press. [Online] Available:https://educatetolead.wordpress.com/2016/02/22/national-policy-on-education6th- edition-2013 
INTERNATIONAL JOURNAL OF ACADEMIC RESEARCH IN BUSINESS AND SOCIAL SCIENCES

Vol. 10, No. 2, Feb, 2020, E-ISSN: 2222-6990 @ 2020 HRMARS

Idris, V. (2013). Students' Perception of strategies for improving delivery of Industrial Work Experience in Delta State University, Abraka: Nigeria Vocational Association Journal,[Online] 18(2).237-

242Available:http://www.sciencepublishinggroup.com/journal/paperinfo?

journalid $=372 \&$ doi $=10$

Jane, I., O., Raymond, U., Patrick, S., O., Uddin, (2017). Bridging Skill Gap to Meet Technical, Vocational Education and Training School Workshop-Workplace Collaboration in the $21^{\text {st }}$ Century: International Journal of Vocational Education and Training Research [Online] (30) 1. 7-13.Available:

http://www.sciencepublishinggroup.com/journal/paperinfo?journalid=372\&doi=

Marcel-Okafor, U. O. (2017). Curriculum and Methods of Teaching Architectural Technology in Nigerian Polytechnics: Challenges and Implications of Practice Performance of the Graduates. International Journal of Informatics. 10 (4), 1410-1417.

Njoku, A., Ihugba, O. A. (2011), Unemployment and Nigerian Economic Growth. (19852009).Proceedings of the 2011 Conference on Teaching, Learning and Change: International Association for Teaching and Learning (IATEL). p1-11.

National Bureau of Statistics Nigeria. (2017). Retrieved from https://tradingeconomics.com/nigeria/unemployment-rate on 5/2/2018

Okwelle, P. C., \& Deebom, M. T. (2017). Technical Vocational Education and Training as a Tool for Sustainable Empowerment of Youth in Delta State, Nigeria International Journal of Innovative Social and Science Education Research, [Online] 5 (11) 29-38. Available: http://seahipaj.org/journals-ci/mar- 2017/IJISSER/full/IJISSER-M-4- 2017.pdf

Ogbanaya, T. C., \& Ekereobong, S. U. (2015). Repositioning Vocational Technical Education and Training (TVET) for Youth Empowerment and National Security in Nigeria.[Online] Journal of Education and Practice, 6 (32) Available: https://files.eric.ed.gov/fulltext/EJ1083539.pdf.

Peter, O. (2014). Building Craftsmanship Skill Development and Nigeria Vision 20:2020: Imperative and Daunting Challenges. Journal of Vocational and Technical Education,[Online] 6 (4), 34-42.Available:https://www.academicjournals.org/journ al/IJVTE/articleabstract/339F22E48379

Shirama, I. \& Dahiru, S. M. (2014). Employability Skills in TVET Curriculum in Nigeria. Journal of Social Behavioural Sciences, 204 (2015), 73-80.

Torruam, J. T., Abur, C. C. (2014), The relationship between unemployment, inflation and crime: An application of co-integration and causality analysis in Nigeria. Journal of Economics and Sustainable Development, 5(4), 131-137

Uddin, P. S. (2013). The Role of Technical and Vocational Education in Poverty Reduction Among youths in Nigeria. Journal of Emerging Trends in Educational Research and Policy Studies [Online](JETERAPS) 4 (4) 613-617. Available: https://pdfs.semanticscholar.org/16bc/4c 1a83250030a8d080fe9afbae52717d2d4 4.pdf

UNESCO. (2009). Regional Contribution to Statistical Information Systems development for Technical and non-formal Technical, Vocational Education and Training. Retrieved on July, 6 from, http://unesdoc.unesco.org/images/0021/002115/211512e.pdf

Wayas, G. G., Selvadurai, S., \& Awang, A. H. (2019). Youth unemployment and terrorism in Nigeria: 
INTERNATIONAL JOURNAL OF ACADEMIC RESEARCH IN BUSINESS AND SOCIAL SCIENCES

Vol. 10, No. 2, Feb, 2020, E-ISSN: 2222-6990 @ 2020 HRMARS

The case of "boko haram." International Journal of Recent Technology and Engineering, 8(2 Special Issue 9), 442-449. https://doi.org/10.35940/ijrte.B1099.0982S919

Salleh, M., Jusoh, A., Embong, R., \& Mamat, M. (2018). Learning Organizational Model in the 21th Century Classroom at Sultan Mahmud Science Secondary School in Terengganu, Malaysia. International Journal of Academic Research in Progressive Education and Development, 7(4), 410-426.Tzotzou, M. D. (2016). Content and Process of the Major Training Programme for State EFL Teachers in Greece: A Critical Review. Multilingual Academic Journal of Education and Social Sciences, 4(1), 13-23.

Kai, D. K., Rahman, B. A. I. (2018). The Impact of Financial Indicators towards Stock Returns of Finance Companies Listed on Bursa Malaysia, International Journal of Academic Research in Accounting, Finance and Management Sciences 8 (3): 128-140. 